\title{
Penerapan Data Mining Pada Transaksi Penjualan Produk Herbalife Nutrition Menggunakan Metode Apriori
}

\author{
Oktavian Nyuwito Hari
}

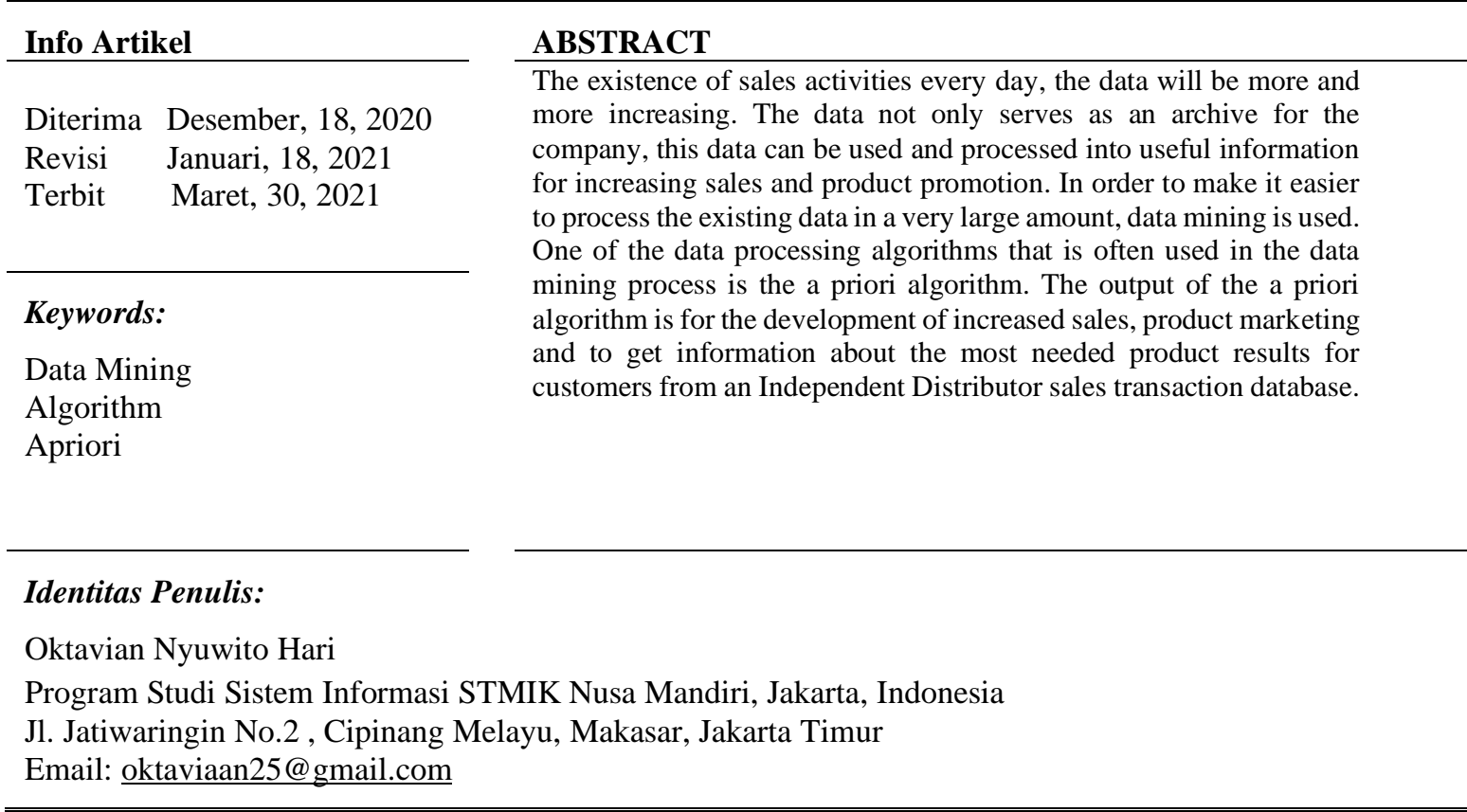

\section{PENDAHULUAN}

Perkembangan bisnis Herbalife Nutrition di Indonesia pada saat ini sudah banyak dikenal oleh orang untuk mengkonsumsi produknya yang membuat tubuh menjadi lebih sehat, mempunyai beberapa cabang, serta menjadi Independent Distributor adalah member yang memafaatkan peluang bisnis dari Herbalife Nutrition serta mencari customer untuk mengkonsumsi produk perusahaan tersebut.

Persaingan yang terjadi dalam dunia bisnis memaksa para pelaku bisnis untuk selalu memikirkan strategisstrategis dan terobosan yang dapat menjamin kelangsungan dari bisnis yang dijalankannya. Dalam rangka menghadapi persaingan bisnis dapat meningkatkan penjualan dan pemasaran produk yang dijual, salah satunya adalah dengan pemanfaatan data penjualan produk [1]. Dengan adanya kegiatan penjualan setiap hari, data semakin lama akan semakin bertambah banyak. Data tersebut tidak hanya berfungsi sebagai arsip bagi perusahaan, data tersebut dapat dimanfaatkan dan diolah menjadi informasi yang berguna untuk peningkatan penjualan dan promosi produk [2].

Salah satu Algoritma pengolahan data yang sering digunakan dalam proses data mining adalah algoritma apriori. Keluaran dari algoritma apriori adalah untuk pengembangan peningkatan penjualan, pemasaran produk serta mendapatkan informasi tentang hasil produk yang paling banyak dibutuhkan pada customer dari suatu database transaksi penjualan Independent Distributor..

\section{METODE}

2.1. Metode Penelitian

Dalam penelitian ini yang menjadi populasi adalah seluruh data transaksi penjualan produk Herbalife Nutrition dari Independent Distributor pada tahun 2019. Sedangkan sampel penelitian adalah 144 data transaksi penjualan Herbalife Nutrition selama satu tahun. Tahapan-tahapan pada penelitian sebagai berikut: 


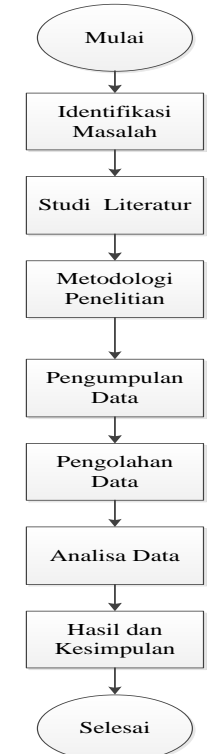

Gambar 1. Tahapan-tahapan Penelitian

\section{HASIL}

Data penjualan pada Independent Distributor Herbalife Nutrition yang akan diteliti adalah data selama satu tahun mulai bulan Januari 2019 sampai dengan bulan Desember 2019.

a. Mencari 3 Nilai Terbesar yang Paling Banyak Terjual

Tabel 1. Data Penjualan pada Bulan Januari 2019

Sumber : Independent Distributor (2019)

\begin{tabular}{|c|l|c|}
\hline No & \multicolumn{1}{|c|}{ Nama Produk } & Total \\
\hline $\mathbf{1}$ & Herbalife Shake Mix & $\mathbf{7}$ \\
\hline 2 & Personalised Protein Powder & 1 \\
\hline $\mathbf{3}$ & Herbal Tea Concentrate & $\mathbf{2}$ \\
\hline 4 & Cell U Loss & 1 \\
\hline $\mathbf{5}$ & Herbalife N-R-G & $\mathbf{3}$ \\
\hline 6 & Herbalifeline & 1 \\
\hline 7 & Tri-Shield & 0 \\
\hline 8 & Niteworks & 1 \\
\hline 9 & Herbal Concentrate Aloe & 1 \\
\hline 10 & Fiber \& Herb Tablets & 0 \\
\hline 11 & Mixed Fiber & 1 \\
\hline
\end{tabular}

Dari hasil data penjualan 3 nilai terbesar pada bulan Januari 2019 yaitu Herbalife Shake Mix sebanyak 7 item, Herbal Tea Concentrate sebanyak 2 item, Herbalife N-R-G sebanyak 3 item.

Tabel 2. Data Penjualan pada Bulan Februari 2019

\begin{tabular}{|c|l|c|}
\hline No & \multicolumn{1}{|c|}{ Nama Produk } & Total \\
\hline $\mathbf{1}$ & Herbalife Shake Mix & $\mathbf{7}$ \\
\hline 2 & Personalised Protein Powder & 2 \\
\hline $\mathbf{3}$ & Herbal Tea Concentrate & $\mathbf{3}$ \\
\hline 4 & Cell U Loss & 1 \\
\hline 5 & Herbalife N-R-G & 2 \\
\hline
\end{tabular}


Sumber : Independent Distributor (2019)

\begin{tabular}{|c|l|c|}
\hline 6 & Herbalifeline & 0 \\
\hline 7 & Tri-Shield & 0 \\
\hline 8 & Niteworks & 1 \\
\hline $\mathbf{9}$ & Herbal Concentrate Aloe & $\mathbf{3}$ \\
\hline 10 & Fiber \& Herb Tablets & 0 \\
\hline 11 & Mixed Fiber & 2 \\
\hline
\end{tabular}

Dari hasil data penjualan 3 nilai terbesar pada bulan Februari 2019 yaitu Herbalife Shake Mix sebanyak 7 item, Herbal Tea Concentrate sebanyak 3 item, Herbal Concentrate Aloe sebanyak 3 item.

Tabel 3. Data Penjualan pada Bulan Maret 2019

Sumber : Independent Distributor (2019)

\begin{tabular}{|c|l|c|}
\hline No & \multicolumn{1}{|c|}{ Nama Produk } & Total \\
\hline $\mathbf{1}$ & Hebalife Shake Mix & $\mathbf{9}$ \\
\hline 2 & Personalised Protein Powder & 1 \\
\hline $\mathbf{3}$ & Herbal Tea Concentrate & $\mathbf{2}$ \\
\hline 4 & Cell U Loss & 1 \\
\hline $\mathbf{5}$ & Hebalife N-R-G & $\mathbf{3}$ \\
\hline 6 & Herbalifeline & 1 \\
\hline 7 & Tri-Shield & 0 \\
\hline 8 & Niteworks & 1 \\
\hline 9 & Herbal Concentrate Aloe & 1 \\
\hline 10 & Fiber \& Herb Tablets & 0 \\
\hline 11 & Mixed Fiber & 1 \\
\hline
\end{tabular}

Dari hasil data penjualan 3 nilai terbesar pada bulan Maret 2019 yaitu Herbalife Shake Mix sebanyak 9 item, Herbal Tea Concentrate sebanyak 2 item, Herbalife N-R-G sebanyak 3 item.

Tabel 4. Data Penjualan pada Bulan April 2019

\begin{tabular}{|c|l|c|}
\hline No & \multicolumn{1}{|c|}{ Nama Produk } & Total \\
\hline $\mathbf{1}$ & Herbalife Shake Mix & $\mathbf{7}$ \\
\hline $\mathbf{2}$ & Personalised Protein Powder & $\mathbf{2}$ \\
\hline 3 & Herbal Tea Concentrate & 1 \\
\hline $\mathbf{4}$ & Cell U Loss & $\mathbf{2}$ \\
\hline 5 & Hebalife N-R-G & 1 \\
\hline 6 & Herbalifeline & 0 \\
\hline 7 & Tri-Shield & 0 \\
\hline 8 & Niteworks & 1 \\
\hline 9 & Herbal Concentrate Aloe & 1 \\
\hline 10 & Fiber \& Herb Tablets & 1 \\
\hline 11 & Mixed Fiber & 1 \\
\hline
\end{tabular}

Sumber : Independent Distributor (2019)

Dari hasil data penjualan 3 nilai terbesar pada bulan April 2019 yaitu Herbalife Shake Mix sebanyak 7 item, Personalised Protein Powder sebanyak 2 item, Cell U Loss sebanyak 2 item.

Tabel 5. Data Penjualan pada Bulan Mei 2019

\begin{tabular}{|c|c|c|}
\hline No & Nama Produk & Total \\
\hline 1 & Herbalife Shake Mix & $\mathbf{1 0}$ \\
\hline
\end{tabular}


Sumber : Independent Distributor (2019)

\begin{tabular}{|c|l|c|}
\hline 2 & Personalised Protein Powder & 1 \\
\hline 3 & Herbal Tea Concentrate & 2 \\
\hline 4 & Cell U Loss & 2 \\
\hline $\mathbf{5}$ & Hebalife N-R-G & $\mathbf{3}$ \\
\hline 6 & Herbalifeline & 1 \\
\hline 7 & Tri-Shield & 1 \\
\hline 8 & Niteworks & 0 \\
\hline $\mathbf{9}$ & Herbal Concentrate Aloe & $\mathbf{4}$ \\
\hline 10 & Fiber \& Herb Tablets & 1 \\
\hline 11 & Mixed Fiber & 1 \\
\hline
\end{tabular}

Dari hasil data penjualan 3 nilai terbesar pada bulan Mei 2019 yaitu Herbalife Shake Mix sebanyak 10 item, Herbal Concentrate Aloe sebanyak 4 item, Herbalife N-R-G sebanyak 3 item.

Tabel 6. Data Penjualan pada Bulan Juni 2019

Sumber : Independent Distributor (2019)

\begin{tabular}{|c|l|c|}
\hline No & \multicolumn{1}{|c|}{ Nama Produk } & Total \\
\hline $\mathbf{1}$ & Herbalife Shake Mix & $\mathbf{6}$ \\
\hline 2 & Personalised Protein Powder & 2 \\
\hline 3 & Herbal Tea Concentrate & 1 \\
\hline 4 & Cell U Loss & 1 \\
\hline $\mathbf{5}$ & Hebalife N-R-G & $\mathbf{4}$ \\
\hline 6 & Herbalifeline & 0 \\
\hline 7 & Tri-Shield & 1 \\
\hline 8 & Niteworks & 1 \\
\hline 9 & Herbal Concentrate Aloe & 2 \\
\hline 10 & Fiber \& Herb Tablets & 1 \\
\hline $\mathbf{1 1}$ & Mixed Fiber & $\mathbf{3}$ \\
\hline
\end{tabular}

Dari hasil data penjualan 3 nilai terbesar pada bulan Juni 2019 yaitu Herbalife Shake Mix sebanyak 6 item, Herbalife N-R-G sebanyak 4 item, Mixed Fiber sebanyak 3 item.

\section{Tabel 7. Data Penjualan pada Bulan Juli 2019}

\begin{tabular}{|c|l|c|}
\hline No & \multicolumn{1}{|c|}{ Nama Produk } & Total \\
\hline $\mathbf{1}$ & Herbalife Shake Mix & $\mathbf{6}$ \\
\hline 2 & Personalised Protein Powder & 2 \\
\hline $\mathbf{3}$ & Herbal Tea Concentrate & $\mathbf{4}$ \\
\hline 4 & Cell U Loss & 1 \\
\hline 5 & Hebalife N-R-G & 2 \\
\hline 6 & Herbalifeline & 1 \\
\hline 7 & Tri-Shield & 0 \\
\hline 8 & Niteworks & 0 \\
\hline $\mathbf{9}$ & Herbal Concentrate Aloe & $\mathbf{5}$ \\
\hline 10 & Fiber \& Herb Tablets & 0 \\
\hline 11 & Mixed Fiber & 2 \\
\hline
\end{tabular}

Sumber : Independent Distributor (2019)

Dari hasil data penjualan 3 nilai terbesar pada bulan Juli 2019 yaitu Herbalife Shake Mix sebanyak 6 item, Herbal Concentrate sebanyak 5 item, Herbal Tea Concentrate 4 item.

Tabel 8. Data Penjualan pada Bulan Agustus 2019 
Sumber : Independent Distributor (2019)

\begin{tabular}{|c|l|c|}
\hline No & \multicolumn{1}{|c|}{ Nama Produk } & Total \\
\hline $\mathbf{1}$ & Herbalife Shake Mix & $\mathbf{4}$ \\
\hline 2 & Personalised Protein Powder & 1 \\
\hline $\mathbf{3}$ & Herbal Tea Concentrate & $\mathbf{3}$ \\
\hline 4 & Cell U Loss & 2 \\
\hline $\mathbf{5}$ & Hebalife N-R-G & $\mathbf{4}$ \\
\hline 6 & Herbalifeline & 0 \\
\hline 7 & Tri-Shield & 0 \\
\hline 8 & Niteworks & 2 \\
\hline 9 & Herbal Concentrate Aloe & 2 \\
\hline 10 & Fiber \& Herb Tablets & 1 \\
\hline 11 & Mixed Fiber & 1 \\
\hline
\end{tabular}

Dari hasil data penjualan 3 nilai terbesar pada bulan Agustus 2019 yaitu Herbalife Shake Mix sebanyak 4 item, Herbalife N-R-G sebanyak 4 item, Herbal Tea Concentrate 3 item.

Tabel 9. Data Penjualan pada Bulan September 2019

\begin{tabular}{|c|l|c|}
\hline No & \multicolumn{1}{|c|}{ Nama Produk } & Total \\
\hline $\mathbf{1}$ & Herbalife Shake Mix & $\mathbf{1 0}$ \\
\hline $\mathbf{2}$ & Personalised Protein Powder & $\mathbf{5}$ \\
\hline 3 & Herbal Tea Concentrate & 3 \\
\hline 4 & Cell U Loss & 1 \\
\hline 5 & Hebalife N-R-G & 1 \\
\hline 6 & Herbalifeline & 0 \\
\hline 7 & Tri-Shield & 1 \\
\hline 8 & Niteworks & 1 \\
\hline $\mathbf{9}$ & Herbal Concentrate Aloe & $\mathbf{5}$ \\
\hline 10 & Fiber \& Herb Tablets & 1 \\
\hline 11 & Mixed Fiber & 2 \\
\hline
\end{tabular}

Sumber : Independent Distributor (2019)

Dari hasil data penjualan 3 nilai terbesar pada bulan September 2019 yaitu Herbalife Shake Mix sebanyak 10 item, Personalised Protein Powder sebanyak 5 item, Herbal Concentrate Aloe 5 item.

Tabel 10. Data Penjualan pada Bulan Oktober 2019

\begin{tabular}{|c|l|c|}
\hline No & \multicolumn{1}{|c|}{ Nama Produk } & Total \\
\hline $\mathbf{1}$ & Herbalife Shake Mix & $\mathbf{8}$ \\
\hline 2 & Personalised Protein Powder & 2 \\
\hline 3 & Herbal Tea Concentrate & 2 \\
\hline $\mathbf{4}$ & Cell U Loss & $\mathbf{5}$ \\
\hline 5 & Hebalife N-R-G & 1 \\
\hline 6 & Herbalifeline & 1 \\
\hline 7 & Tri-Shield & 1 \\
\hline 8 & Niteworks & 1 \\
\hline $\mathbf{9}$ & Herbal Concentrate Aloe & $\mathbf{3}$ \\
\hline 10 & Fiber \& Herb Tablets & 0 \\
\hline 11 & Mixed Fiber & 1 \\
\hline
\end{tabular}

Sumber : Independent Distributor (2019)

Dari hasil data penjualan 3 nilai terbesar pada bulan September 2019 yaitu Herbalife Shake Mix sebanyak 8 item, Cell U Loss sebanyak 5 item, Herbal Concentrate Aloe 3 item. 
Tabel 11. Data Penjualan pada Bulan November 2019

Sumber : Independent Distributor (2019)

\begin{tabular}{|c|l|c|}
\hline No & \multicolumn{1}{|c|}{ Nama Produk } & Total \\
\hline $\mathbf{1}$ & Herbalife Shake Mix & $\mathbf{2}$ \\
\hline 2 & Personalised Protein Powder & 1 \\
\hline 3 & Herbal Tea Concentrate & 1 \\
\hline 4 & Cell U Loss & 1 \\
\hline $\mathbf{5}$ & Hebalife N-R-G & $\mathbf{2}$ \\
\hline 6 & Herbalifeline & 1 \\
\hline 7 & Tri-Shield & 0 \\
\hline 8 & Niteworks & 0 \\
\hline $\mathbf{9}$ & Herbal Concentrate Aloe & $\mathbf{2}$ \\
\hline 10 & Fiber \& Herb Tablets & 1 \\
\hline 11 & Mixed Fiber & 1 \\
\hline
\end{tabular}

Dari hasil data penjualan 3 nilai terbesar pada bulan September 2019 yaitu Herbalife Shake Mix sebanyak 2 item, Herbalife N-R-G sebanyak 2 item, Herbal Concentrate Aloe 2 item.

Tabel 12. Data Penjualan pada Bulan Desember 2019

Sumber : Independent Distributor (2019)

\begin{tabular}{|c|l|c|}
\hline No & \multicolumn{1}{|c|}{ Nama Produk } & Total \\
\hline $\mathbf{1}$ & Hebalife Shake Mix & $\mathbf{5}$ \\
\hline 2 & Personalised Protein Powder & 1 \\
\hline 3 & Herbal Tea Concentrate & 1 \\
\hline 4 & Cell U Loss & 0 \\
\hline $\mathbf{5}$ & Hebalife N-R-G & $\mathbf{4}$ \\
\hline 6 & Herbalifeline & 0 \\
\hline 7 & Tri-Shield & 0 \\
\hline 8 & Niteworks & 1 \\
\hline $\mathbf{9}$ & Herbal Concentrate Aloe & $\mathbf{5}$ \\
\hline 10 & Fiber \& Herb Tablets & 0 \\
\hline 11 & Mixed Fiber & 1 \\
\hline
\end{tabular}

Dari hasil data penjualan 3 nilai terbesar pada bulan September 2019 yaitu Herbalife Shake Mix sebanyak 5 item, Herbal Concentrate Aloe 5 item, Herbalife N-R-G sebanyak 4 item.

\section{b. Melakukan Pengelompokan 3 Produk Herbalife Nutrition Yang Paling Banyak Terjual}

Berdasarkan data penjualan pada bulan Januari sampai Desember 2019 didapatkan pola transaksi dengan menganalisa 3 produk yang paling banyak terjual setiap bulannya dapat dilihat pada tabel berikut ini:

Tabel 13. Pola Transaksi Penjualan Produk Herbalife Pada Bulan Januari - Desember 2019

\begin{tabular}{|c|l|}
\hline Bulan & \multicolumn{1}{c|}{ Itemset } \\
\hline 1 & Hebalife Shake Mix,Hebalife N-R-G, Herbal Tea Concentrate \\
\hline 2 & Hebalife Shake Mix, Herbal Tea Concentrate, Herbal Concentrate Aloe \\
\hline 3 & Hebalife Shake Mix,Hebalife N-R-G, Herbal Tea Concentrate \\
\hline 4 & Hebalife Shake Mix, Personalised Protein Powder, Cell U Loss \\
\hline 5 & Hebalife Shake Mix, Herbal Concentrate Aloe, Herbal Tea Concentrate \\
\hline 6 & Hebalife Shake Mix,Hebalife N-R-G, Mixed Fiber \\
\hline 7 & Hebalife Shake Mix, Herbal Concentrate Aloe, Herbal Tea Concentrate \\
\hline 8 & Hebalife Shake Mix, Hebalife N-R-G, Herbal Tea Concentrate \\
\hline
\end{tabular}




\begin{tabular}{|c|l|}
\hline 9 & Hebalife Shake Mix, Personalised Protein Powder, Herbal Concentrate Aloe \\
\hline 10 & Hebalife Shake Mix, Cell U Loss, Herbal Concentrate Aloe \\
\hline 11 & Hebalife Shake Mix, Hebalife N-R-G, Herbal Concentrate Aloe \\
\hline 12 & Hebalife Shake Mix, Herbal Concentrate Aloe, Hebalife N-R-G \\
\hline
\end{tabular}

\section{c. Membuat Format Tabular}

Format tabular data penjualan 12 bulan/1 tahun tersebut bila dibentuk dapat dilihat pada gambar berikut ini:

\begin{tabular}{|l|c|c|c|c|c|c|c|c|c|c|c|c|}
\hline \multirow{2}{*}{\multicolumn{1}{|c|}{ Nama Produk }} & \multicolumn{10}{|c|}{ Bulan } \\
\cline { 2 - 12 } & $\mathbf{1}$ & $\mathbf{2}$ & $\mathbf{3}$ & $\mathbf{4}$ & $\mathbf{5}$ & $\mathbf{6}$ & $\mathbf{7}$ & $\mathbf{8}$ & $\mathbf{9}$ & $\mathbf{1 0}$ & $\mathbf{1 1}$ & $\mathbf{1 2}$ \\
\hline Herbalife Shake Mix & 1 & 1 & 1 & 1 & 1 & 1 & 1 & 1 & 1 & 1 & 1 & 1 \\
\hline Herbalife N-R-G & 1 & 0 & 1 & 0 & 0 & 1 & 0 & 1 & 0 & 0 & 1 & 1 \\
\hline Herbal Tea Concentrate & 1 & 1 & 1 & 0 & 1 & 0 & 1 & 1 & 0 & 0 & 0 & 0 \\
\hline Herbal Concentrate Aloe & 0 & 1 & 0 & 0 & 1 & 0 & 1 & 0 & 1 & 1 & 0 & 1 \\
\hline Personalised Protein Powder & 0 & 0 & 0 & 1 & 0 & 0 & 0 & 0 & 1 & 0 & 0 & 0 \\
\hline Cell U Loss & 0 & 0 & 0 & 1 & 0 & 0 & 0 & 0 & 0 & 1 & 0 & 0 \\
\hline Mixed Fiber & 0 & 0 & 0 & 0 & 0 & 1 & 0 & 0 & 0 & 0 & 0 & 0 \\
\hline
\end{tabular}

Gambar 2. Format Tabular Data Penjualan

\section{d. Analisis Pola Frekuensi Tinggi}

Pada tahap ini mencari kombinasi item yang memenuhi syarat minimum dari nilai support dalam data. Dengan nilai support yang sudah ditetapkan oleh Independent Distributor Herbalife Nutrition sebesar minimum support $25 \%$ dengan rumus sebagai berikut:

$$
\text { Support (A) }=\frac{\text { Jumlah Transaksi Mengandung A }}{\text { Total Transaksi }} \times 100 \%
$$

\section{Tabel 15. Daftar Support dari Tiap Item}

\begin{tabular}{|l|c|c|}
\hline \multicolumn{1}{|c|}{ Itemset } & Jumlah & Support \\
\hline Herbalife Shake Mix & 12 & $100 \%$ \\
\hline Herbalife N-R-G & 6 & $50 \%$ \\
\hline Herbal Tea Concentrate & 6 & $50 \%$ \\
\hline Herbal Concentrate Aloe & 6 & $50 \%$ \\
\hline
\end{tabular}

Berdasarkan tabel diatas hasil dari 1 itemset yang dapat memenuhi syarat minimum support yaitu sebesar 30\%, maka perhitungan dilanjutkan untuk kombinasi 2 itemset.

Proses mencari 2 itemset dengan jumlah minumum support sebesar $25 \%$ dapat dihitung dengan rumus berikut:

$$
\text { Support }(\mathrm{A})=\mathrm{P}(\mathrm{A} \cap \mathrm{B})=\frac{\text { Jumlah Transaksi Mengandung A dan B }}{\text { Total Transaksi }} \times 100
$$

Berdasarkan hasil perhitungan dari kombinasi 2 itemset yang dapat memenuhi syarat minimum support yaitu sebesar 25\%, maka dilanjutkan untuk kombinasi 3 itemset ada pada tabel berikut ini:

Tabel 16. Daftar Support dari 2 Itemset

\begin{tabular}{|l|c|c|}
\hline \multicolumn{1}{|c|}{ Itemset } & Jumlah & Support \\
\hline Herbalife Shake Mix, Herbalife N-R-G & 6 & $50 \%$ \\
\hline Herbalife Shake Mix, Herbal Tea Concentrate & 6 & $50 \%$ \\
\hline Herbalife Shake Mix, Herbal Concentrate Aloe & 6 & $50 \%$ \\
\hline Herbalife N-R-G, Herbal Tea Concentrate & 3 & $25 \%$ \\
\hline Herbal Tea Concentrate, Herbal Concentrate Aloe & 3 & $25 \%$ \\
\hline
\end{tabular}

Proses mencari 3 itemset dengan jumlah minimum support sebesar $25 \%$ dapat dihitung dengan rumus berikut:

Support $(\mathrm{A})=\mathrm{P}(\mathrm{A} \cap \mathrm{B} \cap \mathrm{C})=\frac{\text { Jumlah Transaksi Mengandung A,B,C }}{\text { Total Transaksi }} \times 100 \%$ 
Berdasarkan hasil diatas dari kombinasi 3 itemset yang dapat memenuhi syarat minimum support yaitu sebesar 25\%, maka dilanjutkan untuk kombinasi 4 itemset ada pada tabel berikut ini:

Tabel 17. Daftar Support dari 3 Itemset

\begin{tabular}{|l|c|c|}
\hline \multicolumn{1}{|c|}{ Itemset } & Jumlah & Support \\
\hline Herbalife Shake, Herbalife N-R-G, Tea Concentrate & 3 & $25 \%$ \\
\hline Herbalife Shake, Tea Concentrate, Concentrate Aloe & 3 & $25 \%$ \\
\hline
\end{tabular}

Proses mencari 4 itemset dengan jumlah minumum support sebesar $25 \%$ dapat dihitung dengan rumus berikut:

$$
\text { Support }(\mathrm{A})=\mathrm{P}(\mathrm{A} \cap \mathrm{B} \cap \mathrm{C} \cap \mathrm{D})=\frac{\text { Jumlah Transaksi Mengandung A,B,C,D}}{\text { Total Transaksi }} \times 100
$$

Berdasarkan hasil diatas dari kombinasi 4 itemset tidak ada yang dapat memenuhi syarat minimum support yaitu sebesar 25\%, maka perhitungan dihentikan atau tidak dilanjutkan ada pada tabel berikut ini:

\section{Tabel 18. Daftar Support dari 4 Itemset}

\begin{tabular}{|c|c|c|}
\hline Itemset & Jumlah & Support \\
\hline Shake, N-R-G, Tea Concentrate, Concentrate Aloe & 0 & $0 \%$ \\
\hline
\end{tabular}

\section{e. Pembentukan Aturan Asosiasi}

Karena pada kombinasi 3 itemset yang memenuhi syarat minimum support, dan mencoba perhitungan pada kombinasi 4 itemset tetapi hasilnya tidak memenuhi syarat, maka perhitungan dihentikan. Minimum Confidence ditentukan sebesar $=50 \%$. Nilai confidence diperoleh dengan menggunakan rumus berikut:

Confidence $=\mathrm{P}(\mathrm{B} \mid \mathrm{A})=\frac{\sum \text { transaksi mengandung A dan } \mathrm{B}}{\sum \text { transaksi mengandung } \mathrm{A}} \times 100 \%$

\section{Tabel 19. Daftar Nilai Confidence Aturan Asosiasi}

\begin{tabular}{|c|c|c|}
\hline Aturan & \multicolumn{2}{|c|}{ Confidence } \\
\hline Jika membeli Herbalife Shake, maka akan membeli Herbalife N-R-G dan Tea Concentrate & $3 / 12$ & $25 \%$ \\
\hline Jika membeli Herbalife N-R-G, maka akan membeli Tea Concentrate dan Herbalife Shake & $3 / 6$ & $50 \%$ \\
\hline nembeli Herbalife Shake dan Herbalife N-R-G & $3 / 6$ & $50 \%$ \\
\hline embeli Herbalife Shake, maka akan membeli Tea Concentrate dan Concentrate Aloe & $3 / 12$ & $25 \%$ \\
\hline Jika membeli Tea Concentrate, maka akan membeli Concentrate Aloe dan Herbalife Shake & $3 / 6$ & $50 \%$ \\
\hline Jika membeli Concentrate Aloe, maka akan membeli Herbalife Shake dan Tea Concentrate & $3 / 6$ & $50 \%$ \\
\hline
\end{tabular}

\section{f. Pembentukan Aturan Asosiasi Final}

Aturan asosiasi final didapatkan dari nilai persentasi yang memenuhi syarat yaitu minimal support dan confidence yang telah ditentukan. Item yang dimaksud terdapat pada tabel berikut ini:

Tabel 22. Daftar Nilai Aturan Asosiasi Final

\begin{tabular}{|l|c|c|}
\hline \multicolumn{1}{|c|}{ Aturan } & Support & Confidence \\
\hline $\begin{array}{l}\text { Jika membeli Herbalife N-R-G, maka akan membeli Tea Concentrate dan } \\
\text { Herbalife Shake }\end{array}$ & $25 \%$ & $50 \%$ \\
\hline $\begin{array}{l}\text { Jika membeli Tea Concentrate, maka akan membeli Herbalife Shake dan } \\
\text { Herbalife N-R-G }\end{array}$ & $25 \%$ & $50 \%$ \\
\hline $\begin{array}{l}\text { Jika membeli Tea Concentrate, maka akan membeli Concentrate Aloe dan } \\
\text { Herbalife Shake }\end{array}$ & $25 \%$ & $50 \%$ \\
\hline $\begin{array}{l}\text { Jika membeli Concentrate Aloe, maka akan membeli Herbalife Shake dan Tea } \\
\text { Concentrate }\end{array}$ & $25 \%$ & $50 \%$ \\
\hline
\end{tabular}

Berdasarkan aturan asosiasi final yang telah dihasilkan pada tabel diatas, dapat diketahui barang yang paling banyak terjual pada Independent Distributor Herbalife adalah Herbalife Shake Mix, Herbalife N-R-G, Herbal Tea Concentrate, Herbal Concentrate Aloe. 


\section{g. Implementasi pada RapidMiner}

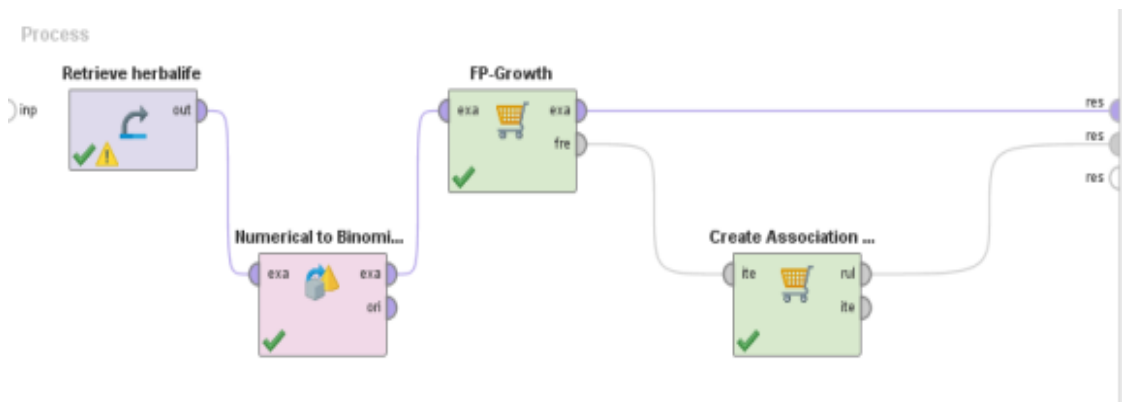

Gambar 3. Tampilan Proses Eksperimen di RapidMiner

\begin{tabular}{|c|c|c|c|}
\hline Frentises & Conchusion & Seppent & coetidence \\
\hline Henvest shate un & Horsulathes & 0.560 & 0500 \\
\hline Heraste Shate Ux & Hersal Tea Concentate & 0.500 & 0500 \\
\hline Hertals: Shate in & Herpal Concertate Hos & e.500 & 0.500 \\
\hline Herixte Ne-G & Hera Tha Conomtrath & 0250 & 0500 \\
\hline Herta Tes Concentale & Herpule NRe-s & Daso & 0500 \\
\hline Hertal Tea Conceltate & Hersa Concentale Aloe & 0250 & 0.500 \\
\hline Henx Concenten ane & Hersu Tra Concentrate & ozso & 0502 \\
\hline Prssonaltsec Pucten Povoser & Hersa Concertate Ast & oves & 0500 \\
\hline Celvitass & Heral Concertate Abe & Do63 & 2500 \\
\hline Pessonalisec Protain Powoler & Ceatuloss & Does & 0500 \\
\hline Cen ULass & Prsonseses Prine Powse: & 0003 & 0500 \\
\hline Henaste N-R-G & 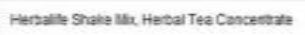 & 0250 & 0500 \\
\hline 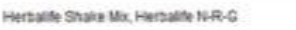 & Heral Tra Concentrate & 0250 & 0500 \\
\hline Merax Tea Concreste & Hende Shat it Hesale NA. & 0250 & 0500 \\
\hline 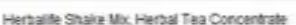 & Harsale NR-G & 0250 & 05000 \\
\hline
\end{tabular}

Gambar 4. Hasil Nilai Support dan Confidence pada RapidMiner

\section{KESIMPULAN}

Dalam perhitungan menggunakan algoritma apriori mendapatkan hasil produk yang paling banyak terjual adalah Herbalife N-R-G dengan nilai support 50\%, Tea Concentrate dengan nilai support 50\%, Herbalife Shake dengan nilai support $100 \%$, dan Concentrate Aloe dengan nilai support 50\%. Dan dapat membantu Independent Distributor tersebut dalam mengembangkan strategi penjualan dengan memberikan informasi untuk mengantisipasi persediaan stok produk apa saja yang dibutuhkan kemudian hari.

\section{REFERENSI}

[1] E. D. Sikumbang, "Penerapan Data Mining Penjualan Sepatu Menggunakan Metode Algoritma Apriori," J. Tek. Komput. AMIK BSI, vol. Vol 4, No., no. September, pp. 1-4, 2018.

[2] V. N. Budiyasari, P. Studi, T. Informatika, F. Teknik, U. Nusantara, and P. Kediri, "Implementasi Data Mining Pada Penjualan Sepatu Dengan Menggunakan Algoritma Apriori,” vol. 2, no. 2, pp. 1-8, 2017. 